\title{
SOSIALISASI PEMBUDAYAAN PENDIDIKAN ANTI KORUPSI BERBASIS MADRASAH UNTUK MENANAMKAN ANTI KORUPSI BAGI SISWA
}

\author{
Nelvitia Purba,SH,M Hum, Ph D, Drs. H. Syafii Zaini ,M. Pd., \\ Enny Fitriani, S.Pd., M.Psi \\ UMN Al Washliyah
}

\begin{abstract}
ABSTRAK
Korupsi beberapa dekade ini merupakan isu sentral dalam penegakan hukum.Berbagai upaya telah dilakukan oleh pemerintah di dalam pemberantasan korupsi ini dengan menetapkan berbagai strategi nasional lebih-lebih di era reformasi, baik melalui Instruksi Presiden Nomor 5 Tahun 2004 Tentang Percepatan Pemberantasan Korupsi, Strategi Nasional Dan Rencana Aksi Pemberantasan Korupsi (Stranas PPK) 2010-2025. Di madrasah/ sekolah adalah merupakan salah satu cara untuk menanamkan nilai-nilai pendidikan antikorupsi di negeri ini adalah dengan memberikan perhatian terhadap pendidikan antikorupsi sejak dini di lembaga pendidikan. Sebagai salah satu jalur pendidikan formal, keberadaan Madrasah pada dasarnya bertujuan untuk meningkatkan pengetahuan siswa untuk melanjutkan pendidikan pada jenjang yang lebih tinggi; meningkatkan pengetahuan siswa untuk mengembangkan diri sejalan dengan perkembangan ilmu pengetahuan, teknologi dan kesenian yang dijiwai ajaran Islam, dan meningkatkan kemampuan siswa sebagai anggota masyarakat dalam mengadakan hubungan timbal balik dengan lingkungan sosial, budaya dan alam sekitarnya yang dijiwai ajaran agama Islam. Pendidikan Agama Islam. Untuk berpartisipasi dalam gerakan pemberantasan dan pencegahan korupsi adalah dapat dilakukan oleh sekolah/madrasah dalam mengembangkan kurikulum Pendidikan Antikorupsi pada Pendidikan Agama Islam pertama adalah proses pendidikan yang harus menumbuhkan kepedulian sosial-normatif, membangun penalaran obyektif, dan mengembangkan perspektif universal pada individu. Kedua, pendidikan harus mengarah pada penyemaian strategis, yaitu kualitas pribadi individu yang konsekuen dan kokoh dalam keterlibatan peran sosialnya kelak pada saat sudah dewasa sebagai generasi penerus bangsa yang antikorupsi.
\end{abstract}

Kata Kunci : Pendidikan Agama Islam, Madrasah, Pencegahan, Korupsi

\begin{abstract}
Corruption which occurs for decades in Indonesia has become a central issue in law enforcement. Numerous efforts have been made by the government in eradicating corruption by setting a range of national strategies especially in the era of reformation, either through Presidential Instruction No. 5 of 2004 on Acceleration of Corruption Eradication and National Strategy and Corruption Eradication Action Plan (Stranas KDP) 2010-2025. One of the ways to instill the value of anti corruption is through educational strategy in madrasah or school. It is done in order to address this issue starting from the early level of educational institutions. As one of the formal education channels, the existence of madrasah is basically aimed at increasing the students' knowledge to continue their education at a higher level; increase the knowledge of students to develop themselves in line
\end{abstract}


with the development of science, technology and arts which are imbued by Islamic teachings, and improve the ability of students as members of the community in conducting mutual relationships with the social environment, culture and natural surroundings which lessons are also imbued by Islamic values and education system. Thus, madrasah can be participating actively in promoting anti-corruption movement which aims at eradicating and preventing corruptions. School / madrasah can also develop Anti-Corruption Education curriculum. This first Islamic education is the educational process that must foster social-normative concern, develop objective reasoning, and develop a universal perspective on the individual. Secondly, education should lead to strategic dissemination with individual qualities that are consistent and robust in the involvement of their future social role as adults with strong anti-corruption values.

Keywords: Corruption, Islamic Religious Education, Madrasah, Prevention.

\section{PENDAHULUAN}

Korupsi, kini sudah menjadi permasalahan serius di negeri ini. Kasus korupsi sudah tidak terhitung lagi jumlahnya. Meskipun sudah ada Komisi Pemberantasan Korupsi(KPK) dan beberapa Instansi anti korupsi lainnya. Namun faktanya negeri ini masih menduduki rangking atas sebagai Negara terkorup didunia. Karena dari itu, korupsi patut menjadi perhatian serius bagi kita semua.

$$
\text { Tindak pidana korupsi }
$$

merambat ke daerah-daerah di Indonesia, tidak terkecuali di Sumatera Utara. Propinsi Sumatera Utara menjadi wilayah dengan kasus korupsi terbanyak di Indonesia. Jumlah ini berdasarkan hasil penelitian yang dilakukan oleh Indonesia ICW periode 1 Juli-31 Des 2010. Berdasarkan data yang dilansir oleh Forum Transparansi Indonesia untuk anggaran (Fitra) wilayah Sumatera Utara dari hasil audit Badan Pemeriksa Keuangan (BPK) pada ikhtisar hasil pemeriksaan (IHP) Semester II tahun 2012 .Menempatkan Sumatera Utara sebagai propinsi terkorup di Indonesia.Propinsi Sumatera Utara menduduki peringkat pertama disusul oleh Propinsi Aceh,
Papua Barat, DKI Jakarta peringkat keempat.

Hal ini tentunya perlu langkah sistematis untuk menanggulanginya. Pemerintah Indonesia telah berusaha keras untuk memerangi korupsi dengan berbagai cara,Salah satunya dengan adanya KPK sebagai lembaga independen yang secara khusus menangani tindak korupsi menjadi upaya pencegahan dan penindakan tindak pidana namun belum mampu juga untuk mengurangi kejahatan korupsi yang terjadi di Indonesia pada umumnya dan di Sumatera Utara pada khususnya.

Korupsi beberapa dekade ini merupakan isu sentral dalam penegakan hukum.Berbagai upaya telah dilakukan oleh pemerintah di dalam pemberantasan korupsi ini dengan menetapkan berbagai strategi nasional lebih-lebih di era reformasi, baik melalui Instruksi Presiden Nomor 5 Tahun 2004 Tentang Percepatan Pemberantasan Korupsi, Strategi Nasional Dan Rencana Aksi Pemberantasan Korupsi (Stranas PPK) 2010-2025, Instruksi Presiden Nomor 9 Tahun 2011 Tentang Rencana Aksi Percepatan Dan Pemberantasan Korupsi 2011, 
Instruksi Presiden Nomor 14 Tahun 2011 Tentang Aksi Percepatan Dan Pemberantasan Korupsi Tahun 2012, Strategi Nasional Pencegahan Dan Pemberantasan Korupsi Jangka Panjang (2012-2025 dan Jangka Menengah (2012-2014).

Dalam kehidupan berbangsa dan bernegara belum tumbuh budaya mutu, budaya malu, dan budaya kerja,baik di kalangan para pemimpin maupun di kalangan masyarakat pada umumnya sehingga sulit untuk mencari tokoh atau figur yang bisa diteladani.Ini merupakan bukti terjadinya pergeseran nilai menuju kehancuran atau pembentukan nilai-nilai baru atas dasar pragmatisme, materialisme, hedonisme, sekularisme, bahkan atheisme.

Kondisi dan kenyataan yang menyedihkan tersebut telah menimbulkan berbagai pertanyaan bagi berbagai pihak, baik di kalangan masyarakat umum maupun di kalangan para ahli pendidikan " Apa yang salah dengan pendidikan nasional sehingga belum berhasil mengembangkan manusia Indonesia seperti yang diamanatkan dalam Pancasila, Undang-Undang Dasar 1945 dan Undang-Undang Sistem Pendidikan Nasional.

Keterlibatan pendidikan formal dalam upaya pencegahan korupsi sebenarnya bukan hal baru, justru memiliki kedudukan strategisantisipatif. Upaya pencegahan budaya korupsi di masyarakat terlebih dahulu dapat dilakukan dengan mencegah berkembangnya mental korupsi pada anak bangsa Indonesia melalui pendidikan. Semangat antikorupsi yang patut menjadi kajian adalah penanaman pola pikir, sikap, dan perilaku antikorupsi melalui sekolah, karena sekolah adalah proses pembudayaan. Sektor pendidikan formal di Indonesia dapat berperan dalam memenuhi kebutuhan pencegahan korupsi dengan menanamkan kepada generasi penerus bangsa untuk antikorupsi. Langkah pencegahan tersebut secara tidak langsung bisa melalui dua pendekatan, pertama: menjadikan peserta didik sebagai target, dan kedua: menggunakan pemberdayaan peserta didik untuk menekan lingkungan untuk peka dan peduli serta tertanam dalam sanubari siswa tersebut untuk antikorupsi.

Di madrasah/ sekolah, nilainilai yang berkembang di masyarakat dikenalkan, dikembangkan, dibina bahkan dihilangkan. Karena hal itulah, salah satu cara untuk menanamkan nilai-nilai pendidikan antikorupsi di negeri ini adalah dengan memberikan perhatian terhadap pendidikan antikorupsi sejak dini di lembaga pendidikan.

Sebagai salah satu jalur pendidikan formal, keberadaan Madrasah pada dasarnya bertujuan untuk meningkatkan pengetahuan siswa untuk melanjutkan pendidikan pada jenjang yang lebih tinggi; meningkatkan pengetahuan siswa untuk mengembangkan diri sejalan dengan perkembangan ilmu pengetahuan, teknologi dan kesenian yang dijiwai ajaran Islam, dan meningkatkan kemampuan siswa sebagai anggota masyarakat dalam mengadakan hubungan timbal balik dengan lingkungan sosial, budaya dan alam sekitarnya yang dijiwai ajaran agama Islam.

Pendidikan untuk mengurangi korupsi berupa pendidikan nilai, yaitu pendidikan untuk mendorong setiap generasi menyusun kembali sistem nilai yang diwarisi oleh nabi Muhammad SAW. Yang bertujuan 
untuk mengetahui konsep Pendidikan Antikorupsi yang direlevansikan dengan tinjauan normatif aspek kurikulum dalam Pendidikan Agama Islam, kemudian mencoba menampilkan model Pendidikan Antikorupsi dalam Pendidikan Agama Islam. Pendidikan Antikorupsi yang dimaksud disini adalah program pendidikan antikorupsi yang secara konsepsional disisipkan pada mata pelajaran yang sudah ada di sekolah dalam bentuk perluasan tema yang sudah ada dalam kurikulum dengan menggunakan pendekatan kontekstual pada pembelajaran antikorupsi, yaitu dengan model Pendidikan Antikorupsi yang dintegrasikan dalam Pendidikan Agama Islam.

\section{METODE PELAKSANAAN}

Metode Yang Digunakan dalam kegiatan Pengabdian adalah dengan Metode Ceramah kepada Guru-guru Pendidikan Agama Islam pada khususnya dan Guru-Guru yang mengajar pada Mata -Mata Pelajaran Umum di Sekolah-sekolah dan Madrasah dan diharapkan dapat diimplementasikan Pendidikan AntiKorupsi ini pada saat mengajarkan Pendidikan Agama Islam khususnya dan mata pelajaran Lainnya yang dimungkinkan untuk diintegrasikan pendidikan AntiKorupsi dan ditanamkan kepada siswa-siswa tersebut dalam aktivitasnya sehari-hari.

\section{HASIL}

Pendirian

Komisi

Pemberantasan Korupsi (KPK) pada 29 September tahun 2002 merupakan sebuah itikad baik dari pemerintahan saat itu. KPK menjadi harapan baru bagi Indonesia untuk mengobati penyakit bangsa yang sudah kronis. Sampai saat ini KPK sudah menunjukan prestasi yang mengaggumkan ditengah dahaga akan pemberantasan korupsi bangsa ini.

Mengingat begitu beratnya tugas KPK dan besarnya akibat yang disebabkan oleh kasus korupsi, maka diperlukan suatu sistem yang mampu menyadarkan semua elemen bangsa untuk sama-sama bergerak mengikis karang korupsi yang telah menggurita. Cara yang paling efektif adalah melalui media pendidikan.

Untuk menciptakan sebuah tatanan kehidupan yang bersih, diperlukan sebuah sistem pendidikan anti korupsi yang berisi tentang sosialisasi bentuk-bentuk korupsi, cara pencegahan dan pelaporan serta pengawasan terhadap tindak pidana korupsi. Pendidikan seperti ini harus ditanamkan secara terpadu mulai dari pendidikan dasar sampai perguruan tinggi. Pendidikan anti korupsi ini akan berpengaruh pada perkembangan psikologis siswa.

Ada dua tujuan yang ingin dicapai dari pendidikan anti korupsi ini, yaitu :

1. Untuk menanamkan semangat anti korupsi pada setiap anak bangsa. Melalui pendidikan ini, diharapkan semangat anti korupsi akan mengalir di dalam darah setiap generasi dan tercermin dalam perbuatan sehari-hari. Sehingga, pekerjaan membangun bangsa karena adanya korupsi dimasa depan tidak ada terjadi lagi. Jika korupsi sudah diminimalisir, maka setiap pekerjaan membangun bangsa akan maksimal karena menghasilkan generasi penerus bangsa yang antikorupsi. 
2. Untuk membangun nilai-nilai dan mengembangkan kapasitas yang diperlukan untuk membentuk posisi siswa-siswa dalam melawan korupsi

3. Menyadari bahwa pemberantasan korupsi bukan hanya tanggung jawab lembaga penegak hukum seperti KPK, Kepolisian dan Kejaksaan agung, melainkan menjadi tanggung jawab setiap anak bangsa.

Pola pendidikan yang sistematik akan mampu membuat siswa mengenal lebih dini hal-hal yang berkenaan dengan korupsi termasuk sanksi yang akan diterima kalau melakukan korupsi. Dengan begitu, akan tercipta generasi yang sadar dan memahami bahaya korupsi, bentukbentuk korupsi dan tahu akan sanksi yang akan diterima jika melakukan korupsi. Sehingga, masyarakat akan mengawasi setiap tindak korupsi yang terjadi dan secara bersama memberikan sanksi moral bagi koruptor. Gerakan bersama anti korupsi ini akan memberikan tekanan bagi penegak hukum dan dukungan moral bagi KPK sehingga lebih bersemangat dalam menjalankan tugasnya.

Tidak hanya itu, pendidikan anti korupsi yang dilaksanakan secara sistemik di semua tingkat institusi pendidikan, diharapkan akan memperbaiki pola pikir bangsa tentang korupsi. Selama ini, sangat banyak kebiasaan-kebiasaan yang telah lama diakui sebagai sebuah hal yang lumrah dan bukan korupsi. Termasuk hal-hal kecil. Misalnya, sering terlambat dalam mengikuti sebuah kegiatan, terlambat masuk sekolah, kantor dan lain sebagainya. Menurut KPK, ini termasuk salah satu bentuk korupsi, korupsi waktu.
Kebiasaan tidak disiplin terhadap waktu ini sudah menjadi lumrah, sehingga perlu dilakukan edukasi kepada masyarakat. Materi ini dapat diikutkan dalam pendidikan anti korupsi ini. Begitu juga dengan halhal sepele lainnya.

Adapun usaha-usaha yang harus dilakukan siswa siswi untuk untuk dapat mencapai tujuan-tujuan dari pendidikan anti korupsi, yaitu dengan :

1. Memahami informasi

Bahaya korupsi biasanya ditunjukkan menggunakan argument ekonomi, sosial dan politik. Siswa tentunya akan sulit untuk memahami,untuk itu perlu 'diterjemahkan' ke dalam bahasa para siswa dengan menunjukkan bagaimana korupsi mengancam kepentingan mereka dan kepentingan keluarga dan temanteman.

2. Mengingat

Tidak diragukan lagi, dengan proses mengulang, anak akan ingat, namun jika yang sama diulang lebih dari tiga kali, anak akan merasa jenuh dan merasa kehilangan hak untuk membuat pilihan bebas. Jadi tidak ada salahnya mengubah bentuk penyediaan informasi dengan cara yang paling tak terduga dan mengesankan (ada variasi)

3. Mempersuasi (Membujuk) diri sendiri untuk bersikap kritis $S$ ikap kritis menjadi sangat kuat bila tidak hanya diberikan, tetapi mengarahkan mereka untuk mengembangkanya dengan penalaran intensif. Efeknya akan lebih kuat jika menggunakan metode pembelajaran aktif.

Dengan adanya pendidikan anti korupsi ini, diharapkan akan lahir generasi tanpa korupsi sehingga 
dimasa yang akan datang akan tercipta Indonesia yang bebas dari korupsi. Harapan awal tentunya ini akan berdampak langsung pada lingkungan sekolah yaitu pada semua elemen pendidikan, seperti kepala sekolah, guru, karyawan dan siswa. Lingkungan sekolah akan menjadi pioneer bagi pemberantasan korupsi dan akan merembes ke semua aspek kehidupan bangsa demi mewujudkan Indonesia yang bebas dari korupsi.

Metode Pendidikan Anti

Korupsi Pakar Pendidikan, Arief Rahman mengemukakan bahwa jika pendidikan anti korupsi lebih tepat dijadikan pokok bahasan dalam mata pelajaran tertentu. Sebuah usulan yang mesti dicermati. Materi pendidikan antikorupsi nantinya bisa saja diselipkan dalam mata pelajaran Pendidikan Pancasila dan Kewarganegaraan (PPKN), Matematika, Bimbingan Karir, Bahasa. Pokok bahasan mencakup kejujuran, kedisiplinan, kesederhanaan, dan daya juang. Selain itu, juga nilai-nilai yang mengajarkan kebersamaan, menjunjung tinggi norma yang ada, dan kesadaran hukum yang tinggi. Disamping itu penanaman nilai tanggung jawab dalam diri setiap siswa juga sangat penting, ini berarti siswa teguh hingga terlaksananya tugas. Tekun melaksanakan kewajiban sampai tuntas. Pengembangan rasa tanggung jawab adalah bagian terpenting dalam pendidikan anak menuju kedewasaan. Menjadi orang yang bermutu sebagai manusia.

Sementara itu Imam Suprayogo juga berpendapat jika Pendidikan Islam harus bisa terintegratif dan berisi serta masuk dalam seluruh relung kehidupan sekolah, dan apalagi di keluarga masing-masing, maka saya berkeyakinan Islam menjadi sebuah budaya dan bahkan peradaban, yaitu budaya dan peradaban Islam. Islam yang selalu mengajarkan tentang hidup santun, menghargai dan hormat pada orang lain, apalagi kepada orang yang lebih tua apalagi guru dan orang tuanya sendiri; penuh kasih sayang, selalu menghindar dari perbuatan rendah seperti berbohong, tidak jujur, tidak amanah(korupsi);

Adapun pelaksanaan yang dapat dilakukan adalah:

Selalu mendekat pada Allah melalui kegiatan spiritual seperti banyak berdzikir (ingat Allah). Sholat berjama'ah, Membudayakan bersedekah setiap hari jumat, Buka Puasa bersama pada Bulan Suci Ramadhan, Memberi Makan Anak yatim, Mengunjungi Panti Asuhan ,Membaca al Qur'an, dan lain-lain.

Dengan ini justru Islam akan lebih terasakan dalam kehidupan sehari-hari. Jadi Pendidikan Islampun juga bisa menjadi Pendidikan yang menjauhkan dari tindakan untuk antikorupsi. H. Abdul Djamil (Rektor IAIN Walisongo Semarang) dia berpendapat jika peran agama untuk pemberantasan korupsi sebenarnya bagus yakni mengajarkan dalam bentuk Pendidikan, berlomba-lomba meraih kebajikan dan menjauhi dari segala kemungkaran atau kejahatan. Sayangnya hidup manusia yang beragama, tidak pernah konsisten. Manusia beragama masih bergantung pada situasi dan kondisi. Jika di lingkungan tempat ibadah, patuh pada hukum agama, namun sebaliknya jika kondisi memungkinkan, jauh pada aturan agama. Karena itu, korupsi yang juga terjadi di tingkat masyarakat bawah sangat mungkin terinspirasi dari 
korupsi di tingkat atas. Sistem pemerintahan yang ada belum mampu menciptakan masyarakat bersih karena dalam diri pribadi tersimpan watak korup.

$$
\text { Selain itu, Pusat }
$$

Pengembangan Pesantren dan Masyarakat (P3M) yang berbasis kultural kaum Nahdliyin telah melaksanakan sejumlah bahtsul masa'il (diskusi hukum Islam) mengenai korupsi serta menerbitkannya dalam beberapa buku. Diantaranya Buku yang berjudul Menolak Korupsi: Membangun Kesalehan Sosial, berisi kumpulan naskah khotbah Jum'at yang mengambil tema korupsi. Buku terbitan P3M lain adalah Korupsi di Negeri Kaum Beragama: Ikhtiar Membangun Fikih Antikorupsi, berisikan kumpulan makalah yang disajikan dalam acara Munas Bahtsul Masail NU (Mei 2004). Buku berjudul NU Melawan Korupsi: Kajian Tafsir dan Fiqih yang diterbitkan oleh Tim Kerja Gerakan Nasional Pemberantasan Korupsi Pengurus Besar Nahdlatul Ulama (GNPK PB NU), 2006. Buku ini mengelaborasi fenomena korupsi di Indonesia serta membahasnya melalui pandangan Islam dan strategi pemberantasannya. Buku berjudul Ayat-Ayat Korupsi yang dibuat Hakim Muda Harahap, M'Ag dan diterbitkan oleh Gama Media, 2009. Buku ini hanya membahas ayat-ayat al-qur'an yang relevan dengan tindakan korupsi dan hukuman bagi perilaku korupsi.

\section{KESIMPULAN}

Jika Pendidikan AntiKorupsi bisa di Integrasikan ke dalam lingkungan Pendidikan Agama Islam apalagi di lingkungan keluarga masing-masing, maka Antikorupsi menjadi sebuah budaya dan bahkan peradaban, yaitu budaya dan peradaban Islam. Islam yang selalu mengajarkan tentang hidup santun, menghargai dan hormat pada orang lain, apalagi kepada orang yang lebih tua apalagi guru dan orang tuanya sendiri; penuh kasih sayang, selalu menghindar dari perbuatan rendah seperti berbohong, tidak jujur, tidak amanah(korupsi);.

Adapun pelaksanaan yang dapat dilakukan adalah:

- Selalu mendekat pada Allah melalui kegiatan spiritual seperti banyak berdzikir (ingat Allah).

- Sholat berjama'ah.

- Membudayakan bersedekah setiap hari jumat

- Buka Puasa bersama pada Bulan Suci Ramadhan

- Memberi Makan Anak yatim

- Mengunjungi Panti Asuhan

- Membaca al Qur'an dan lainlain.

\section{REFERENSI}

Aziz Syamsuddin,2011,Tindak Pidana Khusus,Sinar Grafika Jakarta.

Andi Hamzah,2012,Pemberantasan Korupsi Melalui Hukum Pidana Nasional Dan Internasional,PT.RajaGrafindo Persada Jakarta

Burhan Ashshofa, 2010, Metode Penelitian Hukum, Rineka Cipta.

Damiyati Zuchdi,2013,Model Pendidikan Karakter, Perpustakaan Nasional.

Elwi Danil, 2011, Korupsi Konsep Tindak Pidana Dan Pemberantasannya, PT. RajaGrafindo Persada Jakarta. Muchlas Samani,2011,Konsep Dan Model Pendidikan 
Karakter,PT.Remaja

Rosdakarya.

Mansyur Hamdan,2002,Pendidikan

Kewarganegaraan,Gramedia

Pustaka Utama Jakarta.

Syaiful Bakhri,2009,Pidana Denda

Dan Korupsi,Total Media Jakarta.

$\begin{array}{lr}\text { Suyadi,2012,Strategi } & \text { Pembelajaran } \\ \text { Pendidikan } & \text { Karakter, } \\ \text { PT.Remaja Rosdakarya. } \\ \text { Zubaedi,2011,Desain Pendidikan } \\ \text { Karakter Konsepsi Dan } \\ \text { Aplikasinya Dalam Lembaga } \\ \text { Pendidikan,Kencana Prenada } \\ \text { Media Group Jakarta. }\end{array}$

Suyadi,2012,Strategi Pembelajaran Pendidikan Karakter,

Karakter Konsepsi Dan

Aplikasinya Dalam Lembaga Media Group Jakarta. 